\title{
TINGKAT MOTIVASI MASYARAKAT DESA BENTENG GAJAH TERHADAP INTRODUKSI AYAM BURAS HASIL TEKNOLOGI IN OVO FEEDING
}

\author{
Djoni Prawira Rahardja, Veronica Sri Lestari, Muhammad Rahman Hakim, \\ Kusumandari Indah Prahesti dan Mohammad Ridwan Bahar \\ Program Studi Peternakan - Universitas Hasanuddin, Makassar \\ Jalan Perintis Kemerdekaan KM.10, Tamalanrea Indah, Kota Makassar 90245
}

Alamat korespondensi: djonipra@gmail.com

\begin{abstract}
ABSTRAK
Tujuan dari kegiatan pengabdian masyarakat ini adalah untuk mengetahui tingkat motivasi masyarakat terhadap introduksi ayam buras hasil teknologi in ovo feeding. Pengabdian masyarakat dilakukan di desa Benteng Gajah, Kecamantan Moncongloe, Kabupaten Maros. Jumlah masyarakat penerima bantuan ayam buras hasil in ovo feeding adalah 7 orang. Setiap orang mendapat paket bantuan ayam buras sebanyak 50 ekor umur sehari (DOC) dan bantuan pakan untuk 1 bulan. Data diperoleh melalui observasi dan wawancara menggunakan kuesioner. Variabel dalam kuesioner terdiri dari 3 jenis berdasarkan kebutuhan akan keberadaan (existence), kebutuhan untuk berhubungan (Relatedness) dan kebutuhan untuk berkembang (growth). Jumlah pertanyaan sebanyak 15 buah. Skala Likert digunakan untuk menilai jawaban dari setiap pertanyaan, yaitu skore 1 untuk tidak setuju, skor 2 untuk netral dan skor 3 untuk setuju. Data dianalisa secara deskriptif. Hasil pengamatan menunjukkan bahwa tingkat motivasi masyarakat Desa Benteng Gajah terhadap introduksi ayam buras hasil teknologi in ovo feeding dapat dikategorikan "tinggi".
\end{abstract}

Kata Kunci : In ovo feeding, motivasi, ayam buras.

\section{PENDAHULUAN}

Ayam lokal merupakan salah satu penghasil daging dan telur bagi masyarakat. Menurut Rahardja et al., (2018), ayam lokal ini biasanya disebut "Ayam Kampung atau Ayam Buras" atau ayam asli Indonesia yang memiliki karakteristik morfologi yang berbeda. Meskipun memiliki potensi untuk dikembangkan, ayam asli memiliki kendala utama dalam produksi dan reproduksi. Dalam produksi daging, mereka tumbuh sangat lambat dan mengalami konversi pakan yang buruk. Dalam reproduksi, mereka memiliki produksi telur yang rendah. Selain latar belakang genetik mereka, kinerja rendah dari ayam asli dapat dikaitkan dengan input manajemen yang rendah, penggerusan gratis untuk pakan di sekitar rumah petani di siang hari, karena sebagian besar memelihara tradisional yang luas oleh petani untuk pendapatan tambahan mereka. Salah satu upaya 
untuk meningkatkan produktivitas ayam buras adalah melalui teknik in ovo feeding.

Injeksi bahan eksogen in ovo tampaknya bisa menjadi pendekatan alternatif untuk meningkatkan kinerja ayam asli. Investigasi sebelumnya sebagian besar pada breed eksotik menunjukkan bahwa injeksi in ovo nutrisi ke dalam telur tetas adalah untuk memasok nutrisi yang memadai yang menghasilkan peningkatan daya tetas telur dan kinerja setelah menetas berikutnya, berat badan pada usia pemasaran dan kualitas karkas ayam (Shafey et al., 2013 dan Tako et al., 2014).

Menurut Cardeal et al. (2015), manipulasi in ovo dapat mengurangi hasil inkubasi ketika diterapkan pada awal perkembangan embrionik. Hasil terbaik dari pemberian in ovo ditemukan ketika suplementasi dilakukan dengan karbohidrat. Berdasarkan hasil penelitian yang dilakukan oleh Hakim et al. (2019), pemberian Glutamin untuk mendapatkan anak ayam yang lebih besar pada saat penetasan dapat dilakukan pada hari ke 7, 9 dan 11 , bahkan dengan daya tetas yang lebih rendah.

Menurut Effendi (2015), motivasi merupakan suatu proses yang menjelaskan intensitas, arah dan ketekunan individu untuk mencapai tujuannya. Berdasarkan teori hierarki kebutuhan Maslow, teori $\mathrm{X}$ da $\mathrm{Y}$ maupun teori motivasi kontemporer, arti motivasi merupakan alasan yang mendasari sebuah perbuatan yang dilakukan oleh individu. Sedangkan konsep motivasi dipakai untuk menggambarkan hubungan antara harapan, dengan tujuan, kebutuhan, dan rangsangan.

Motivasi merupakan faktor penentu keberhasilan peternak. Peternak yang memiliki motivasi yang tinggi akan berdampak pada kelangsungan usaha yang mereka jalankan, dalam hal ini hasil yang mereka peroleh dapat memenuhi kebutuhan sehari-hari dan secara tidak langsung akan meningkatkan kesejahteraan hidup peternak. Berdasarkan hasil penelitian yang dilakukan oleh Nursal (2016), faktorfaktor yang mempengaruhi motivasi beternak ayam buras adalah pendapatan, hiburan, pakan melimpah dan lahan luas.

$\begin{array}{ccc}\text { Desa } & \begin{array}{c}\text { Benteng } \\ \text { mempunah }\end{array} \\ \text { potensi } & \text { untuk }\end{array}$
pengembangan ayam buras. Hal ini disebabkan karena lahan masih luas dan jauh dari pemukiman penduduk. Tujuan dari pengabdian masyarakat ini adalah untuk mengetahui tingkat motivasi masyarakat penerima bantuan ayam buras hasil in ovo feeding.

\section{METODE KEGIATAN}

Tahap pertama yang dilakukan adalah melakukan survei lokasi. Lokasi pelaksanaan program pengabdian masyarakat adalah di desa Benteng Gajah, Kecamatan Moncongloe, Kabupaten Maros. Setelah lokasi ditentukan, tahap berikutnya adalah menentukan masyarakat yang mau menerima dan memelihara ayam buras. Sebanyak 7 
orang dipilih secara purposive sampling untuk menerima bantuan paket ayam buras hasil dari in ovo feeding sebanyak 50 ekor umur DOC (Day Old Chick = ayam umur sehari), pakan ternak untuk satu bulan.

Tahap selanjutnya adalah pelaksanaan kegiatan pengabdian. Pada tahap ini masyarakat diminta untuk menjawab 15 pertanyaan tentang tingkat motivasi. Sekala Likert digunakan dengan skor tertinggi adalah 3 dan terendah adalah 1. Untuk mengukur tingkat motivasi, digunakan acuan teori ERG (Eksistence, Relatedness, Growth) yang dikemukakan oleh Clayton Aldelfer sebagai pengembangan dari teori Maslow. Ketiga indikator tersebut dapat dijelaskan sebagai berikut:

1. Kebutuhan akan keberadaan (exictence): adalah suatu kebutuhan akan tetap bisa hidup sesuai dengan tingkat kebutuhan tingkat rendah dari Maslow yaitu meliputi kebutuhan fisiologis dan kebutuhan akan rasa aman. Contoh yaitu kebutuhan peternak untuk memperoleh pendapatan dari beternak ayam buras.

2. Kebutuhan berhubungan (relatedness): mencakup kebutuhan untuk berinteraksi dengan orang lain. Kebutuhan ini sesuai dengan kebutuhan afiliasi dari Maslow. Contoh yaitu kebutuhan peternak untuk di terima dalam pergaulan lingkungan masyarakat tempat tinggal.
3. Kebutuhan untuk berkembang (growth need): kebutuhan yang mendorong seseorang untuk memiliki pengaruh yang kreatif dan produktif terhadap diri sendiri atau lingkungan. Realisasi dari kebutuhan penghargaan dan perwujudan diri dari Maslow. Contoh pengakuan dari masyarakat terhadap keberhasilan beternak.

Data yang diperoleh kemudian ditabulasi dan dianalisis secara deskriptif menggunakan persentase dan total skor.

\section{HASIL DAN PEMBAHASAN}

\section{Karakteristik peternak ayam buras}

Rata-rata umur peternak adalah 34,75 tahun dengan umur termuda adalah 14 tahun dan umur tertua adalah 62 tahun. Artinya peternak masih berada pada usia produktif, sehingga diharapkan mampu untuk memelihara ayam buras. Semua responden berjenis kelamin laki-laki (100\%) dengan tingkat pendidikan mayoritas SMU (57,1\%). Tingkat pendidikan yang cukup tinggi merupakan modal untuk dapat menerima materi inovasi peternakan.

\section{Tingkat motivasi peternak ayam buras}

Untuk mengetahui tingkat motivasi ditentukan melalui penghitungan skor. Skor tertinggi diperoleh dengan perkalian antara skor tinggi (3) dengan jumlah item pertanyaan dari masing-masing 
indikator motivasi. Skor minimum diperoleh dari perkalian antara skor terendah (1) dengan jumlah item pertanyaan. Hasil perhitungan skor dari masing-masing item pertanyaan, selanjutnya dibuat kategori dengan menghitung rerata. Sehingga tingkat motivasi digunakan dua kategori yaitu tertinggi dan terendah dengan menghitung frekuensi hasil skor jawaban responden.

Tabel 1. Tingkat Motivasi Masyarakat Penerima Bantuan Ayam Buras Hasil In-

Ovo Feeding

\begin{tabular}{lcc}
\hline Variabel & Nilai bobot & Keterangan \\
\hline Kebutuhan akan keberadaan (Eksistence) & 48 & - \\
Kebutuhan akan hubungan (Relatedness) & 57 & - \\
Kebutuhan untuk berkembang (Growth) & 46 & - \\
\hline & 151 & Tinggi \\
\hline
\end{tabular}

Berdasarkan

hasil

perhitungan diperoleh nilai total untuk 3 indikator yaitu (Eksistence, Relatedness, Growth), nilai skor tertinggi adalah 180 dan terendah adalah 60. Motif tertinggi yaitu pada kebutuhan peternak untuk di terima dalam pergaulan lingkungan masyarakat tempat tinggal yaitu 57 (Relatedness). Pada dasarnya manusia merupakan mahluk sosial, sehingga dalam dirinya selalu muncul keinginan untuk mengadakan interaksi sosial dengan masyarakat sekitar. Motif urutan kedua yaitu Eksistense (48). Bahwasanya masyarakat mau menerima bantuan ayam buras hasil in ovo feeding karena mereka berharap pendapatannya akan meningkat. Motif terendah adalah Growth (46). Pada dasarnya masyarakat tidak terlalu ingin menunjukkan pengaruhnya terhadap lingkungan tentang keberhasilannya dalam beternak ayam buras. Secara keseluruhan total skor adalah 151, artinya tingkat motivasi masyarakat Desa Benteng Gajah terhadap introduksi ayam buras hasil teknologi in ovo feeding termasuk kategori tinggi (Tabel 1).

\section{KESIMPULAN DAN SARAN}

Berdasarkan hasil pengamatan, dapat disimpulkan bahwa tingkat motivasi masyarakat penerima paket ayam buras hasil dari teknik in ovo feeding termasuk kategori tinggi.

Disarankan kepada masyarakat penerima bantuan paket ayam buras untuk memelihara sebaik-baiknya ayam buras mereka, supaya dapat meningkatkan pendapatan keluarga. Disamping itu perlu adanya pembinaan dan penyuluhan tentang ayam buras dari instansi terkait secara intensif dan kontinyu. 


\section{UCAPAN TERIMA KASIH}

Ucapan terima kasih disampaikan kepada Universitas Hasanuddin yang telah memberikan dukungan finansial dalam pelaksanaan pengabdian ini.

\section{DAFTAR PUSTAKA}

Cardeal PC, Caldas EOL, Lara LJR and Rocha JSR. 2015. In ovo feeding and its effects on performance of newlyhatched chicks. World's Poultry Science Journal. 71(4): 655-662. DOI: https://doi.org/10.1017/S0043 933915002445.

Effendi U. 2015. Asas Manajemen. Edisi Kedua. PT. RajaGrafindo Persada. Jakarta.

Hakim AR, Daryatmo D, Rahardja DP, Pakiding W. 2019. Hatching performance of Indonesian native chicken supplemented by LGlutamine at different days of incubation. Chalaza Journal of Animal Husbandry. 4(1): 1-5.
Nursal, J. 2016. Faktor-Faktor yang memotivasi masyarakat dalam usaha beternak ayam buras di Desa Bonto Bulaeng, Kecamatan Bonto Tiro, Kabupaten Bulukumba. Skripsi. Jurusan Ilmu Peternakan. Fakultas Sains dan Teknologi. Universitas Islam Negeri Alauddin Makassar.

Rahardja DP, Lestari VS, Hakim MR. 2018. Application of in ovo injection of L-Glutamine for improving productivity of Indonesian native chicken: hatchability and hatching time. IOP Conference Series Earth and Environmental Science 157(1):012071.

Shafey TM, Sami AS, Abouheif MA. 2013. The effect in ovo feeding of LGlutamine on hatchability performance and hatching time of meat-type breeder eggs. J. Anim. Vet. Adv., 12(1): 135-139.

Tako E, Ferket PR and Uni Z. 2004. Effects of in ovo feeding of carbohydrates and beta-hydroxybeta-methylbutyrate on the development of chicken intestine. Poult. Sci. 83: 2023 - 28. 